\title{
Studi Distribusi Partikel Sedimen Tersuspensi Di Teluk Balikpapan Dengan Menggunakan Pemodelan Dispersal
}

\author{
Fitri Suciaty $^{1}$, Putri Kemili², Tommy Harkey ${ }^{2}$ \\ ${ }^{1}$ Jurusan Teknik Sipil, Fakultas Teknik Sipil dan Perencanaan, ITENAS, Bandung \\ ${ }^{2}$ Research and Consultancy ASR Indonesia, Kantor Taman A9/lot 8,9 Unit D - \\ Megakuningan, Jakarta \\ Email: fitrisuciaty@itenas.ac.id
}

\begin{abstract}
ABSTRAK
Salah satu permasalahan penting sebagai akibat berbagai aktivitas di Teluk Balikpapan adalah erosi dan sedimentasi yang dapat menyebabkan degradasi lingkungan seperti peningkatan kekeruhan, pencemaran air, degradasi mangrove yang mengancam ekosistem perairan dan juga pendangkalan pada kawasan pelabuhan laut Balikpapan. Beberapa kajian erosi dan sedimentasi terdahulu di DAS Teluk Balikpapan menyatakan kandungan sedimen tersuspensi yang tinggi terdapat pada muara sungai-sungai utama yang bermuara ke Teluk Balikpapan. Pemodelan numerik hidrodinamika dan pemodelan dispersal dua dimensi untuk partikel sedimen tersuspensi dilakukan untuk memperoleh gambaran faktor-faktor hidrodinamika yang berpengaruh dan juga identifikasi pola distribusi partikel sedimen tersuspensi di Teluk Balikpapan. Simulasi sebaran partikel sedimen tersuspensi dilakukan pada beberapa skenario sumber partikel, yaitu di muara Sungai Semoi, hulu dan muara Sungai Riko, muara Sungai Wein, dan di bagian mulut Teluk Balikpapan. Simulasi dilakukan selama 15 hari untuk musim barat dan musim timur untuk mengetahui variasi sebarannya terhadap kondisi musim.
\end{abstract}

Kata kunci: partikel sedimen tersuspensi, hidrodinamika, pemodelan dispersal, transpor sedimen.

\begin{abstract}
One of the important problems as a result of various activities in Balikpapan Bay is erosion and sedimentation which can cause environmental degradation such as increased turbidity, water pollution, mangrove degradation which threatens aquatic ecosystems and also silting of the Balikpapan sea port area. Some previous erosion and sedimentation studies in the Balikpapan Bay watershed state that high concentration of suspended sediment is found in the estuaries of the main rivers that flow into Balikpapan Bay. Numerical hydrodynamic modeling and two-dimensional dispersal modeling for suspended sediment particles are carried out to obtain an overview of influential hydrodynamic factors and also to identify distribution patterns of suspended sediment particles in Balikpapan Bay. Simulations on the distribution of suspended sediment particles were carried out in a number of particle source scenarios, i.e. at the Semoi River estuary, upstream and Riko River estuary, Wein River estuary, and at the mouth of Balikpapan Bay. The simulation is carried out for 15 days for the west and east seasons to find out the seasonal variation.
\end{abstract}

Keywords: suspended sediment particles, hydrodynamic, dispersal modeling, sediment transport. 


\section{PENDAHULUAN}

Teluk Balikpapan diketahui memiliki berbagai aktivitas yang menyebabkan terjadinya kemunduran kualitas lingkungan. Salah satu penyebabnya yaitu adanya erosi di hulu sungai dan sedimentasi pada muara-muara sungai yang bermuara ke Teluk Balikpapan. Erosi dan sedimentasi yang terjadi dapat mengakibatkan peningkatan kekeruhan, pencemaran air, degradasi mangrove dan juga pendangkalan pada kawasan pelabuhan laut Balikpapan.

Berdasarkan kajian sedimentasi yang dilakukan oleh Coastal Research Center/University of Rhode Island (CRC/URI) dan Bappenas diketahui sedimen yang terangkut oleh sungai-sungai yang bermuara ke Teluk Balikpapan relatif besar dan dapat menyebabkan pendangkalan di sekitar Teluk Balikpapan [1]. Hasil model numerik 3-Dimensi yang dilakukan oleh Susyanto [2] memperlihatkan deposisi terjadi di hulu sungai Semoi dan Sungai Riko, yaitu masing-masing sebesar $4 \mathrm{~mm}$ dan $3 \mathrm{~mm}$ dalam waktu 1 bulan. Sedangkan untuk erosi terjadi di Teluk Balikpapan bagian timur, dengan nilai maksimum mencapai $68 \mathrm{~mm}$ [2].

Berbagai studi terdahulu mengenai erosi dan sedimentasi di Teluk Balikpapan lebih banyak mengkaji laju sedimentasi yang terjadi pada muara-muara sungai, namun tidak mengkaji bagaimana pola sebarannya di wilayah Teluk Balikpapan secara keseluruhan dan bagaimana variasi musimannya. Sinaga, dkk., [3], melakukan pemodelan transpor sedimen untuk mengetahui pola sebaran sedimen tersuspensi di wilayah Teluk Balikpapan dengan domain model perairan di sekitar muara Sungai Wain saja. Pada penelitian ini, studi mengenai pola distribusi partikel sedimen tersuspensi di seluruh area Teluk Balikpapan dilakukan untuk memperoleh gambaran faktor-faktor hidrodinamika yang berpengaruh dan juga identifikasi pola sebaran dan variasi sebaran partikel sedimen terhadap kondisi musim.

Pemodelan numerik hidrodinamika dan model dispersal 2-dimensi dilakukan dengan menggunakan 3DD Suite Model [4] [5]. Sedimen tersuspensi pada model dispersal diasumsikan sebagai suatu partikel konservatif. Simulasi sebaran partikel sedimen tersuspensi dilakukan pada 5 skenario sumber partikel, yaitu di muara Sungai Semoi, hulu dan muara Sungai Riko, muara Sungai Wein, dan di bagian mulut Teluk Balikpapan dengan variasi musiman, yaitu saat musim barat dan musim timur selama 15 hari untuk masing-masing musim.

\section{METODOLOGI}

Untuk mengetahui pola distribusi partikel sedimen tersuspensi di Teluk Balikpapan, terlebih dahulu dilakukan pemodelan hidrodinamika pasang surut. Selanjutnya dilakukan pemodelan dispersal, dimana hasil simulasi dari pemodelan dispersal ini sangat dipengaruhi oleh arus dan elevasi dari model hidrodinamika yang telah dilakukan sebelumnya. 3DD Suite adalah model yang digunakan pada studi ini. Proses fisik dan juga dinamik yang terjadi di sekitar pesisir dapat dengan baik dipahami dan dikuantifikasi dengan menggunakan model ini baik dalam 2 ataupun 3 dimensi [4].

\subsection{Model Hidrodinamika}

Persamaan pembangun yang digunakan dalam model hidrodinamika adalah persamaan momentum dan kontinuitas sebagai berikut [4]: 


$$
\begin{gathered}
\frac{\partial u}{\partial t}+u \frac{\partial u}{\partial x}+v \frac{\partial u}{\partial y}+w \frac{\partial u}{\partial z}-f v=-g \frac{\partial \zeta}{\partial \mathrm{x}}-\frac{1}{\rho} \frac{\partial \mathrm{P}}{\partial \mathrm{x}}+\mathrm{A}_{\mathrm{H}}\left(\frac{\partial^{2} \mathrm{u}}{\partial \mathrm{x}}+\frac{\partial^{2} \mathrm{u}}{\partial \mathrm{y}}\right)+\frac{\partial}{\partial z}\left(\frac{\mathrm{N}_{z} \partial \mathrm{u}}{\partial z}\right) \\
\frac{\partial v}{\partial t}+u \frac{\partial v}{\partial x}+v \frac{\partial v}{\partial y}+w \frac{\partial v}{\partial z}+f u=-g \frac{\partial \zeta}{\partial y}-\frac{1}{\rho} \frac{\partial P}{\partial y}+A_{H}\left(\frac{\partial^{2} v}{\partial x}+\frac{\partial^{2} v}{\partial y}\right)+\frac{\partial}{\partial z}\left(N_{z} \frac{\partial v}{\partial z}\right) \\
w=-\frac{\partial}{\partial x} \int_{-\hbar}^{z} u d z-\frac{\partial}{\partial y} \int_{-\hbar}^{z} v d z
\end{gathered}
$$

dimana $t$ adalah waktu, $u$ dan $v$ adalah kecepatan horizontal arah $x$ dan $y, w$ adalah kecepatan vertikal (positif kearah atas), $h$ kedalaman, $g$ pecepatan gravitasi, $\zeta$ elevasi muka air di atas datum horizontal, $f$ parameter coriolis, $P$ komponen baroklinik tekanan, $A_{H}$ koefisien horizontal eddy dan $N_{Z}$ koefisien vertikal viskositas eddy [6].

\subsection{Kondisi batas}

Dua kondisi batas di permukaan (wind-stress) dan di dasar (bottom-stress) diberlakukan sebagai berikut [4]:

Kondisi batas di permukaan pada $\mathrm{z}=0$ yaitu :

$$
\rho N_{z} \frac{\partial u}{\partial z}=\tau_{x}^{g}, \rho N_{z} \frac{\partial v}{\partial z}=\tau_{y}^{g}, \frac{\partial \zeta}{\partial t}+u \frac{\partial \zeta}{\partial x}+v \frac{\partial \zeta}{\partial y}=w^{g}
$$

dimana $\tau_{x}^{s}, \tau_{y}^{s}$ menunjukkan komponen stress angin:

$$
\tau_{x}^{g}=\rho \alpha \gamma|W| W_{-} x, \tau_{y}^{s}=\rho \alpha \gamma|W| W_{y}
$$

$\rho$ adalah densitas air; $W$ kecepatan angin pada $10 \mathrm{~m}$ di atas muka air laut, sedangkan $W_{x}$ dan $W_{y}$ adalah komponen kecepatan angin arah $x$ and $y, \gamma$ koefisien drag angin, $\rho a$ densitas udara [6]. Kondisi batas di dasar laut, $z=-h$, yaitu:

$$
\rho N_{z} \frac{\partial u}{\partial z}=\tau_{x}^{h}, \rho N_{z} \frac{\partial v}{\partial z}=\tau_{y}^{h}
$$

dimana $\tau_{x}^{g}, \tau_{y}^{s}$ menunjukkan komponen stress dasar:

$$
\tau_{x}^{h}=\frac{\rho g w_{h}\left(w_{h}^{2}+w_{h}^{2}\right)^{0.5}}{c^{2}}, \tau_{y}^{h}=\frac{\rho g w_{h}\left(w_{h}^{2}+w_{h}^{2}\right)^{0.5}}{c^{2}}
$$

dengan $u_{k}, v_{h}$ merupakan arus di dasar danC adalah koefisien Chezy. Dalam bentuk logaritmik, $C=18 \log _{10}\left(0.37 h / z_{0}\right)$, dimana $z_{0}$ adalah panjang kekasaran (roughness length) [6].

\subsection{Model dispersal}

Pemodelan dispersal dilakukan untuk melihat sebaran partikel yang di-input pada suatu sumber, misalnya seperti sedimen yang berasal dari sungai, sampah yang berasal dari daratan, ataupun tumpahan minyak yang terjadi di lepas pantai. POL3DD dari software 3DD suite digunakan pada studi ini untuk memodelkan partikel sedimen tersuspensi. Pemodelan hidrodinamika pasang surut terhubung dengan model POL3DD. Grid model yang digunakan pada model POL3DD sama 
dengan grid model hidrodinamika yang telah dilakukan sebelumnya. Adapun konsentrasi $(C)$ partikel pada model ini diatur oleh persamaan adveksi/ difusi berikut [5]:

$$
\frac{\partial C}{\partial t}=\frac{\partial}{\partial x}\left(E_{x} \frac{\partial C}{\partial x}-U C\right)+\frac{\partial}{\partial y}\left(E_{y} \frac{\partial C}{\partial y}-V C\right)+\frac{\partial}{\partial z}\left(E_{z} \frac{\partial C}{\partial z}+\omega_{g} C-W C\right)-k C+S_{g}
$$

dimana $t$ adalah waktu; $x, y, z$ adalah koordinat spasial orthogonal; $E x, E y, E z$ dan adalah koefisien difusivitas eddy; $W s$ adalah kecepatan pengendapan air jenuh oleh gravitasi; $U, V, W$ komponen kecepatan horizontal dan vertikal fluida; $k$ adalah koefisien peluruhan untuk tracer nonkonservatif [6].

\subsection{Data dan Model Set-Up}

Pemodelan hidrodinamika dilakukan untuk area yang mencakup muara Teluk Balikpapan dengan lebar grid model dalam arah- $x$ dan arah- $y$ adalah $100 \mathrm{~m}$ dan jumlah grid model sebesar $635 \times 510$ seperti pada Gambar 1. Muara Teluk Balikpapan memiliki kedalaman yang relatif dangkal yaitu kurang dari -20 meter dengan beberapa lokasi yang memiliki kedalaman lebih dalam yaitu kurang -50 meter, misalnya sisi tengah badan sungai serta alur pelayaran yang telah dilakukan dredging / pengerukan.
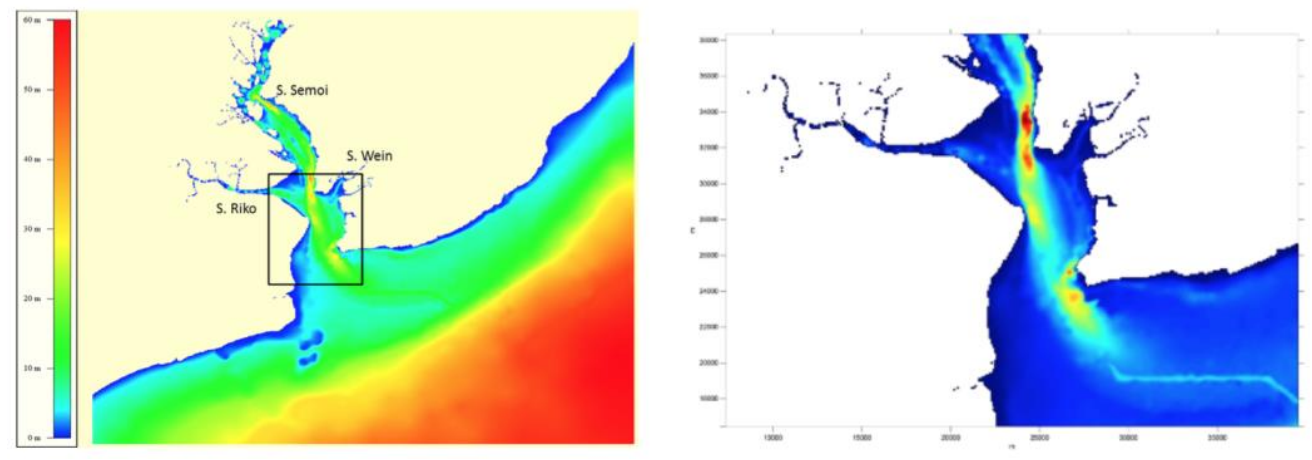

Gambar 1. Batimetri Model

Input pasang surut berupa timeseries elevasi (m) yang berasal dari model global Tide Model Drive (TMD) [7] dengan 8 komponen utama pasang surut yaitu M2, S2, N2, O1, K1, P1, K2, dan Q1 pada setiap titik batas terbuka. Selain pasang surut, data kecepatan dan arah angin juga diperhitungkan pada pemodelan, yaitu data kecepatan angin komponen $u$ dan $v$ yang didapatkan dari ERA-INTERIM [8] untuk data yang mewakili musim barat (Januari) dan musim timur (Agustus) dengan interval waktu data 6 jam. Pada saat musim barat (Januari), angin dominan bertiup dari Barat Laut dengan kecepatan dominan sebesar $\geq 2,5-4,0 \mathrm{~m} / \mathrm{s}$. Sedangkan pada saat musim timur (Agustus), angin dominan bertiup dari tenggara dengan kecepatan dominan yang lebih besar dibandingkan saat musim barat, yaitu berkisar antara 1,0-5,5 m/s. Simulasi untuk pemodelan hidrodinamika dilakukan selama 30 hari untuk masing-masing musim (musim barat dan musim timur).

Input debit sungai di tiga batas terbuka daerah model yaitu dengan menggunakan nilai kecepatan arus pada musim barat di Sungai Semoi sebesar $0,71 \mathrm{~m} / \mathrm{s}$, di Sungai Riko sebesar 0,31 m/s, dan di Sungai Wein $0,23 \mathrm{~m} / \mathrm{s}$ sesuai dengan data CRC/URI - Bappenas. Sedangkan pada musim timur, nilai kecepatan arus yang diberikan di Sungai Semoi lebih kecil, yaitu sebesar 0,2 m/s, di Sungai Riko sebesar $0,31 \mathrm{~m} / \mathrm{s}$, dan di Sungai Wein $0,23 \mathrm{~m} / \mathrm{s}$ [1]. 


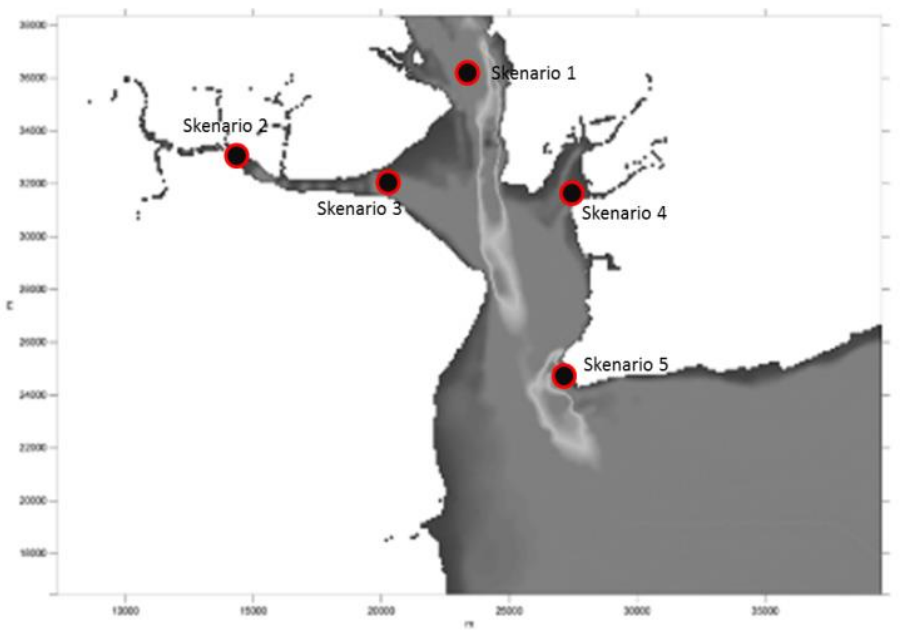

Gambar 2. Skenario lokasi titik pelepasan partikel konservatif

Selanjutnya kecepatan, pola arus, dan juga elevasi muka air hasil pemodelan hidrodinamika digunakan pada pemodelan dispersal untuk mengetahui pola sebaran partikel sedimen tersuspensi di area model. Pola sebaran partikel sedimen tersuspensi diamati saat arus pasang purnama dan juga perbani pada musim barat dan musim timur. Pada modul POL3DD, partikel sedimen tersuspensi diasumsikan sebagai partikel konservatif yang kemudian disimulasikan untuk mengetahui sebaran partikel yang dilepaskan pada titik tertentu. Simulasi dilakukan selama 15 hari baik pada musim barat maupun saat musim timur dengan particle release setiap 1 jam pada beberapa titik di daratan dan di lepas pantai. Terdapat 5 Skenario lokasi titik pelepasan partikel konservatif yang dijalankan, yaitu di muara Sungai Semoi, hulu dan muara Sungai Riko, muara Sungai Wein, dan di bagian mulut Teluk Balikpapan. Lokasi titik pelepasan partikel konservatif yang dijalankan pada 5 skenario model dapat dilihat pada Gambar 2 berikut.

\section{HASIL DAN PEMBAHASAN}

\subsection{Validasi Hasil Pemodelan}

Hasil simulasi divalidasi dengan menggunakan data pengukuran elevasi muka air pada koordinat $116.808^{\circ} \mathrm{E}$ dan $1,28^{\circ} \mathrm{S}$. Grafik perbandingan hasil pemodelan dan data pengukuran dapat dilihat pada Gambar 3. Perbandingan elevasi muka air dari hasil pemodelan dan data pengukuran menunjukan kesesuaian yang cukup baik, baik saat pasang purnama maupun saat pasang perbani. Terdapat perbedaan elevasi muka air sebesar $0,2 \mathrm{~m}$ antara hasil model dan data pengukuran di lapangan.

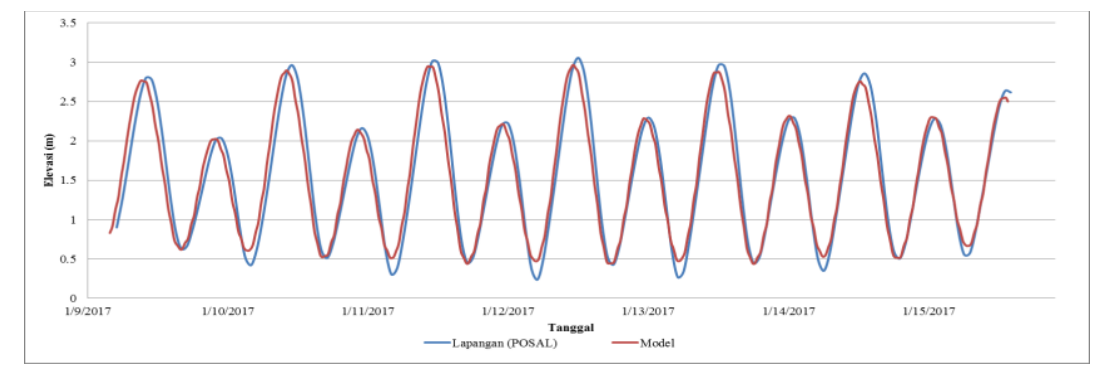

Gambar 3. Perbandingan elevasi muka air hasil pemodelan dengan data pengukuran lapangan 


\subsection{Hasil Simulasi Model Hidrodinamika}

Untuk mengetahui pola sebaran partikel sedimen tersuspensi di Teluk Balikpapan, maka perlu diketahui terlebih dahulu pola hidrodinamika dari elevasi muka air dan pola arus di area tersebut. Gambar 4 menunjukan hasil simulasi model hidrodinamika saat musim barat di Teluk Balikpapan.

Besarnya input kecepatan arus Sungai Semoi pada saat musim barat $(0,7 \mathrm{~m} / \mathrm{s})$ mengakibatkan hampir setiap saat massa air tawar dari Sungai tersebut bergerak menuju muara Teluk Balikpapan dengan kecepatan mencapai $2 \mathrm{~m} / \mathrm{s}$ di daerah Kariangau yang memiliki batimetri sangat kompleks. Kedalaman yang relatif lebih dalam di bagian badan Sungai Semoi dan juga Teluk Balikpapan bagian tengah mengakibatkan kecepatan arus yang lebih besar di area tersebut dibandingkan dengan area disekitarnya. Sedangkan di pesisir teluk sisi barat dan timur dan juga Sungai Riko, kecepatan arus masih dipengaruhi oleh pasang surut. Arah arus di area ini bergerak bolak-balik dengan besar kecepatan yang relatif kecil karena batimetri yang relatif lebih dangkal dibandingkan di sekitarnya.

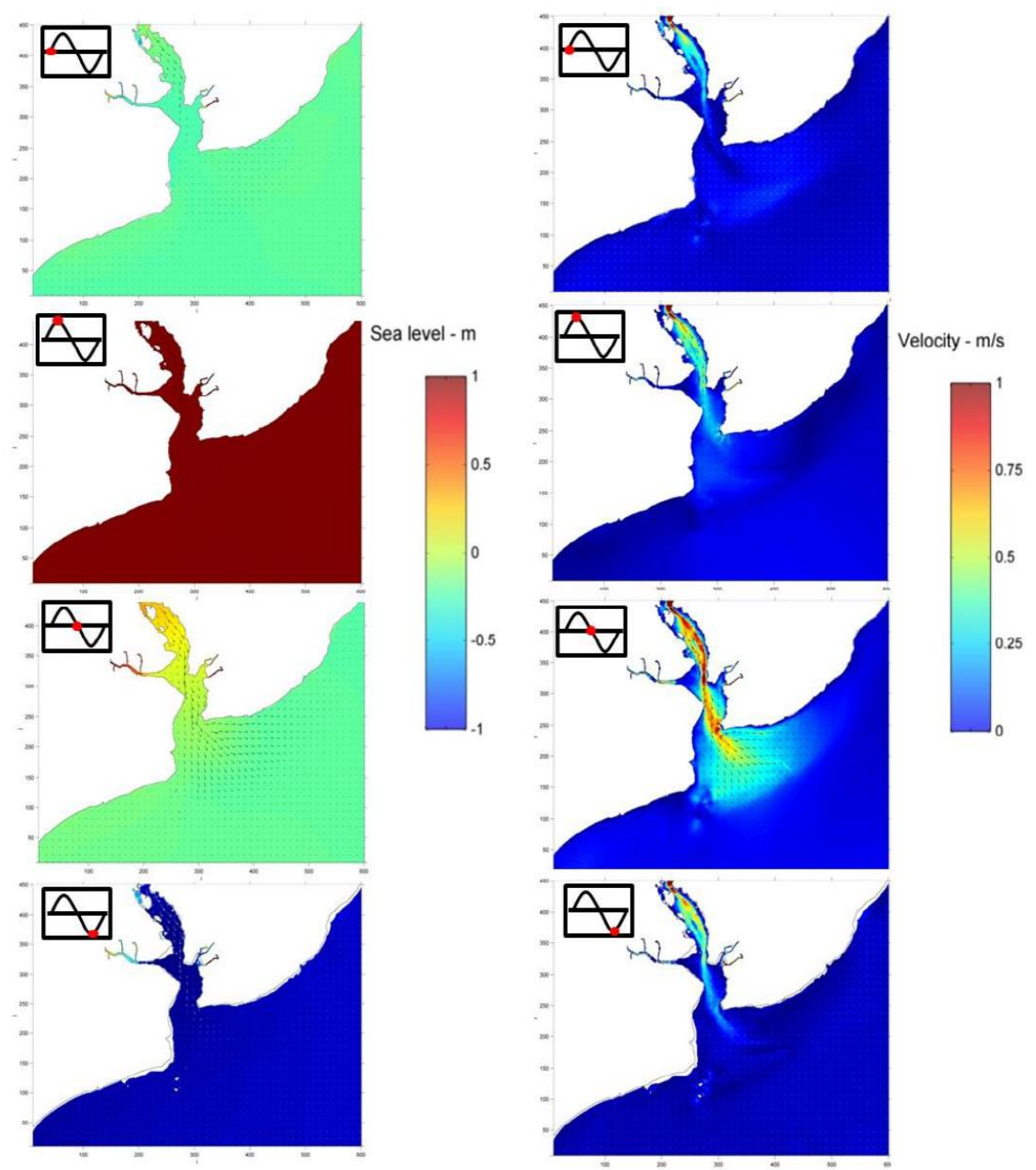

Gambar 4. Pola elevasi dan arus saat musim barat

Saat menuju pasang, kecepatan arus di muara Teluk Balikpapan kurang dari 0,1 m/s dengan arah dominan menuju lepas pantai. Hal ini disebabkan karena arus yang bergerak menuju ke arah pesisir Teluk Balikpapan menahan besarnya arus dari sungai dengan yang berlawanan, sehingga di muara Teluk Balikpapan kecepatan menjadi kecil. Saat pasang maksimum, kecepatan arus rata- 
rata di Teluk Balikpapan sebesar $0,1 \mathrm{~m} / \mathrm{s}$ baik di pesisir maupun di lepas pantai. Sedangkan pada saat menuju surut, kecepatannya meningkat mencapai $1 \mathrm{~m} / \mathrm{s}$ di sisi tengah teluk dan mencapai 0,3 $\mathrm{m} / \mathrm{s}$ di daerah pesisir Teluk Balikpapan. Hal ini dikarenakan kondisi arus pada saat tersebut merupakan akumulasi dari massa air yang bergerak surut ke arah lepas pantai dan massa air dari sungai. Daerah Kariangau yang berada di bagian utara domain model terlihat memiliki kecepatan yang relatif lebih besar dari daerah lainnya di sepanjang waktu pasang surut karena massa air dari hulu sungai bergerak melalui celah sempit pada kedalaman yang lebih dangkal.

Simulasi juga dilakukan untuk musim timur. Gambar 5 adalah hasil model berupa parameter elevasi dan kecepatan arus saat musim timur. Secara umum besarnya kecepatan arus di musim timur lebih kecil daripada saat musim barat baik di lepas pantai maupun di sungai-sungai dan Teluk Balikpapan dengan nilai kecepatan yang relatif lebih tinggi terjadi di daerah dengan batimetri yang lebih dalam seperti di badan sungai dan teluk sisi tengah.

Pada Gambar 5 terlihat bahwa saat menuju pasang, arus yang bergerak pasang ke arah pesisir Teluk Balikpapan menahan besarnya arus dari sungai karena arahnya yang berlawanan, sehingga di muara Teluk Balikpapan kecepatan menjadi kecil (kurang dari $0,1 \mathrm{~m} / \mathrm{s}$ ) dengan arah dominan menuju lepas pantai. Saat pasang maksimum, kecepatan arus rata-rata yaitu $0,1 \mathrm{~m} / \mathrm{s}$ baik di Kariangau, pesisir, maupun di lepas pantai. Saat menuju surut, arus menjadi besar mencapai 0,5 $\mathrm{m} / \mathrm{s}$ di sisi tengah teluk dan mencapai $0,2 \mathrm{~m} / \mathrm{s}$ di daerah pesisir Teluk Balikpapan. Saat surut minimum, kecepatan arus berkurang yaitu rata-rata sebesar $0,1 \mathrm{~m} / \mathrm{s}$.
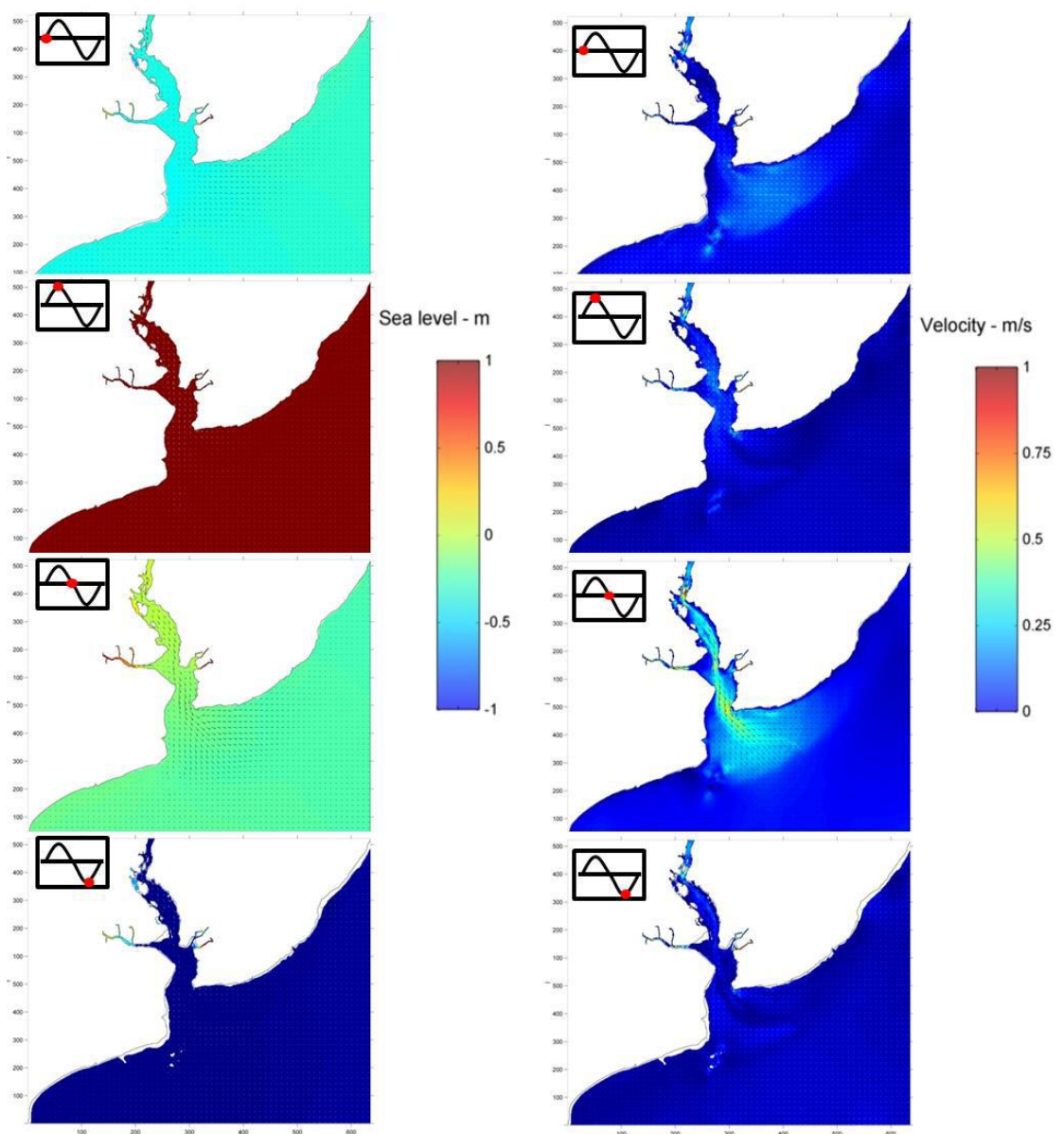

Gambar 5. Pola elevasi dan arus saat musim timur 
Gambar 6 menunjukan pola arus residu di area model pada saat musim barat dan saat musim timur. Arus residu ini digambarkan untuk mengetahui arus non pasang surut yang berpengaruh di Teluk Balikpapan. Arus residu di Teluk Balikpapan memiliki nilai yang lebih besar pada musim barat yaitu mencapai lebih dari $0,5 \mathrm{~m} / \mathrm{s}$ terutama di sisi tengah Teluk Balikpapan dibandingkan pada musim timur yang hanya mencapai $0,2 \mathrm{~m} / \mathrm{s}$ terutama di sisi tengah Teluk Balikpapan yang disebabkan karena input kecepatan arus Sungai Semoi di musim barat yang lebih besar $(0,7 \mathrm{~m} / \mathrm{s})$ dibandingkan pada musim timur $(0,2 \mathrm{~m} / \mathrm{s})$ dengan arah arus residu yang bergerak ke arah lepas pantai baik saat musim barat maupun musim timur.

Kondisi batimetri juga mempengaruhi besar dan arah arus residu yang terlihat dari adanya turbulensi di sisi barat muara Teluk Balikpapan serta perbedaan kecepatan arus residu antara sisi tengah dengan sisi pesisir badan Teluk Balikpapan yang diakibatkan oleh perbedaan batimetri. Hal ini menunjukkan bahwa batimetri serta pengaruh lokal (debit sungai) sangat dominan mempengaruhi kondisi hidrodinamika di dalam Teluk Balikpapan. Sedangkan di lepas pantai Teluk Balikpapan, nilai arus residu yang lebih kecil menggambarkan pasang surut yang dominan di lokasi tersebut.

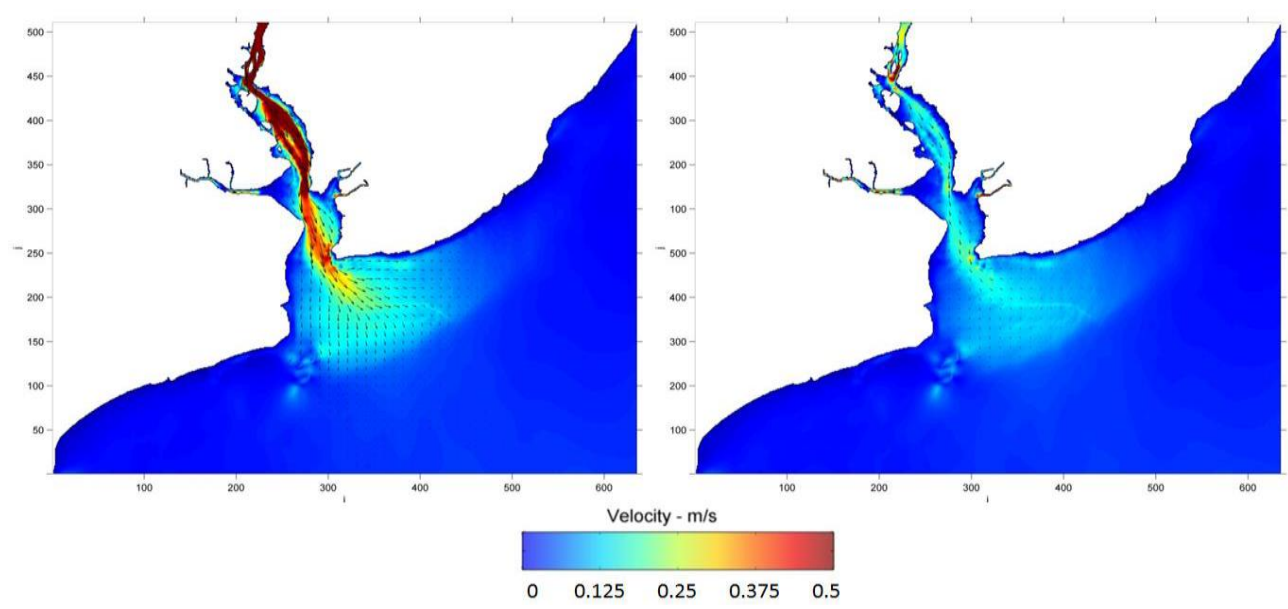

Gambar 6. Pola arus residu Teluk Balikpapan musim barat (kiri) dan musim timur (kanan)

\subsection{Hasil Simulasi Model Dispersal}

Hasil simulasi model dispersal, yaitu sebaran partikel sedimen tersuspensi selama 15 hari saat musim barat dan musim timur untuk Skenario 1- Skenario 5 ditunjukan oleh Gambar 7 - Gambar 12. Dari hasil simulasi tersebut terlihat adanya perbedaan pola sebaran partikel sedimen tersuspensi antara musim barat dan musim timur di hampir semua skenario. Perbedaan pola tersebut disebabkan oleh perbedaan arah angin dan juga dipengaruhi oleh perbedaan input kecepatan arus pada tiap musim di masing masing sungai. Selain itu, adanya partikel sedimen tersuspensi yang bergerak berlawanan dengan arah gerak partikel secara umum serta arah pergerakan partikel sedimen tersuspensi yang bolak-balik menandakan bahwa pasang surut juga memberi pengaruh pada pergerakan partikel.

Secara umum, sebaran partikel sedimen tersuspensi di musim barat bergerak lebih jauh dan lebih melebar daripada sebaran partikel tersuspensi di musim timur karena nilai kecepatan arus sungai ketika musim barat lebih besar $(0,71 \mathrm{~m} / \mathrm{s})$ daripada ketika musim timur $(0,2 \mathrm{~m} / \mathrm{s})$. Untuk sumber partikel sedimen tersuspensi yang dilepas di muara Teluk (Skenario 5), seluruh partikel sedimen 
bergerak menuju lepas pantai, tidak ada partikel sedimen yang bergerak ke arah pesisir baik pada musim barat maupun musim timur, karena debit arus yang cukup besar. Sedangkan, untuk sumber partikel sedimen yang dilepas di sisi barat sungai (Skenario 2 dan 3), maka partikel akan bergerak sepanjang pesisir Teluk Balikpapan sisi barat dan tidak ada yang bergerak ke sisi timur teluk.Sebaliknya, untuk sumber partikel sedimen yang dilepas di sisi timur sungai (Skenario 4), maka partikel sedimen akan bergerak sepanjang pesisir Teluk Balikpapan sisi timur dan tidak ada yang bergerak ke sisi barat teluk.
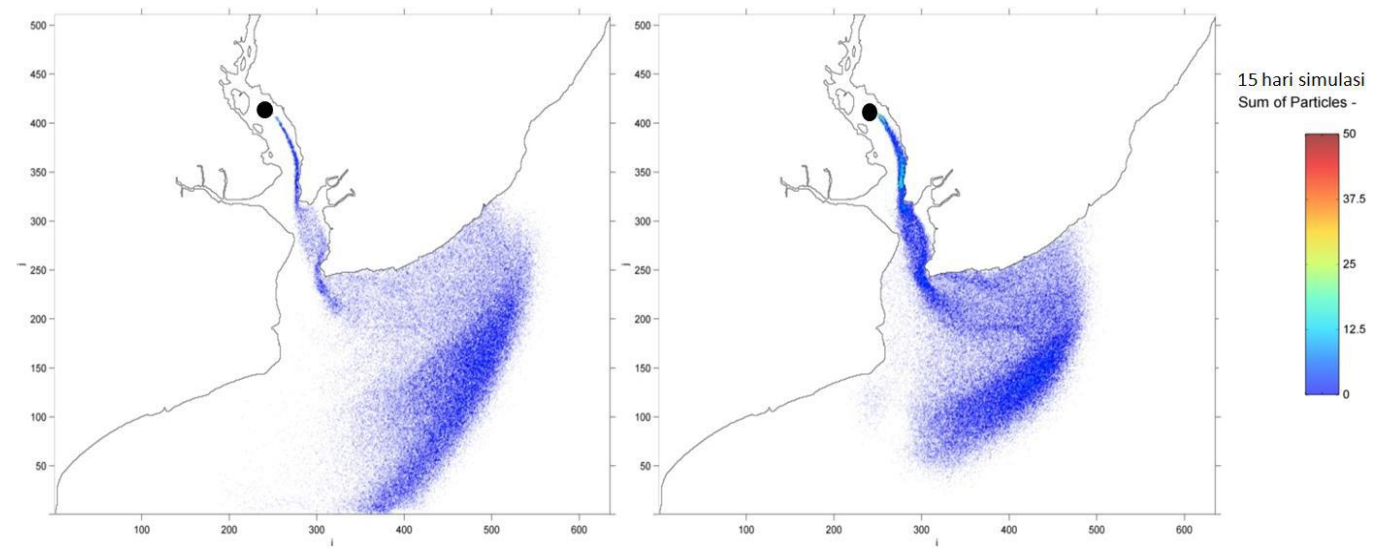

Gambar 7. Pola distribusi partikel selama 15 hari simulasi untuk Skenario 1 pada musim barat (kanan) dan musim timur (kiri)

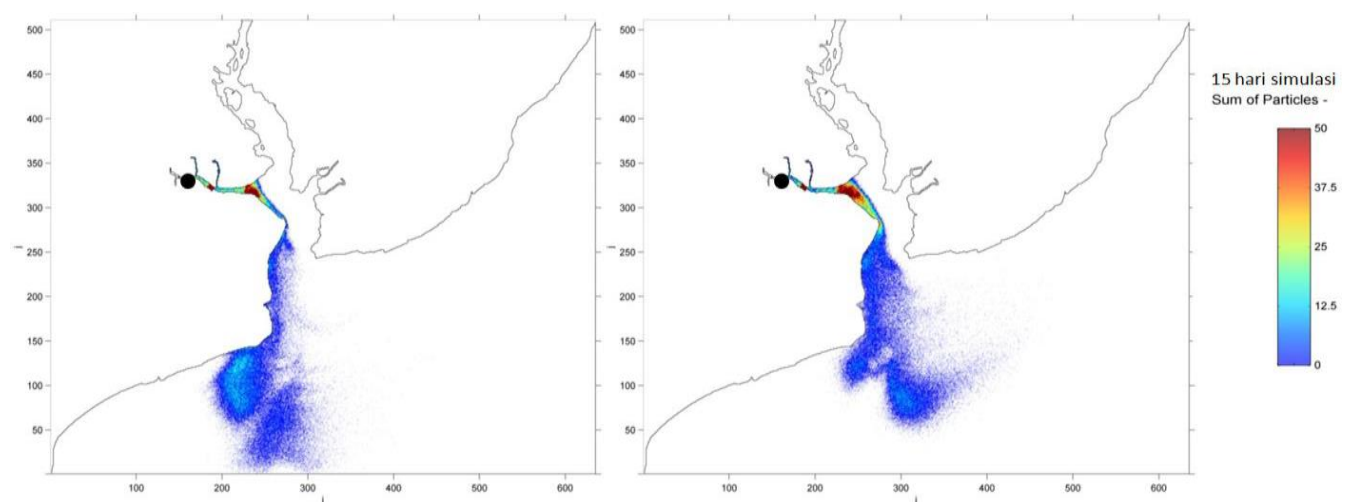

Gambar 8. Pola distribusi partikel selama 15 hari simulasi untuk Skenario 2 pada musim barat (kanan) dan musim timur (kiri)

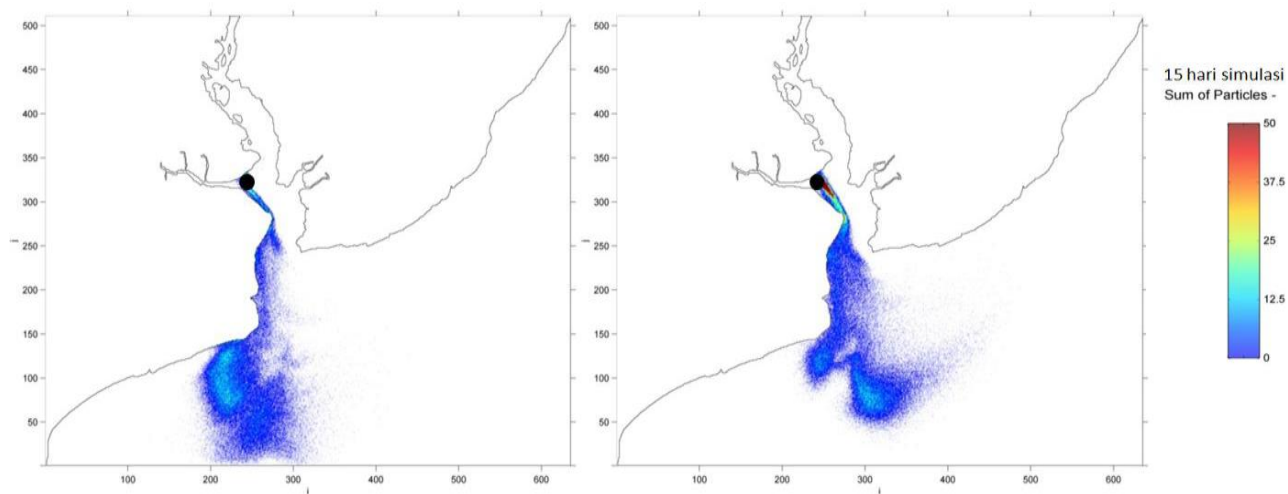

Gambar 9. Pola distribusi partikel selama 15 hari simulasi untuk Skenario 3 pada musim barat (kanan) dan musim timur (kiri) 


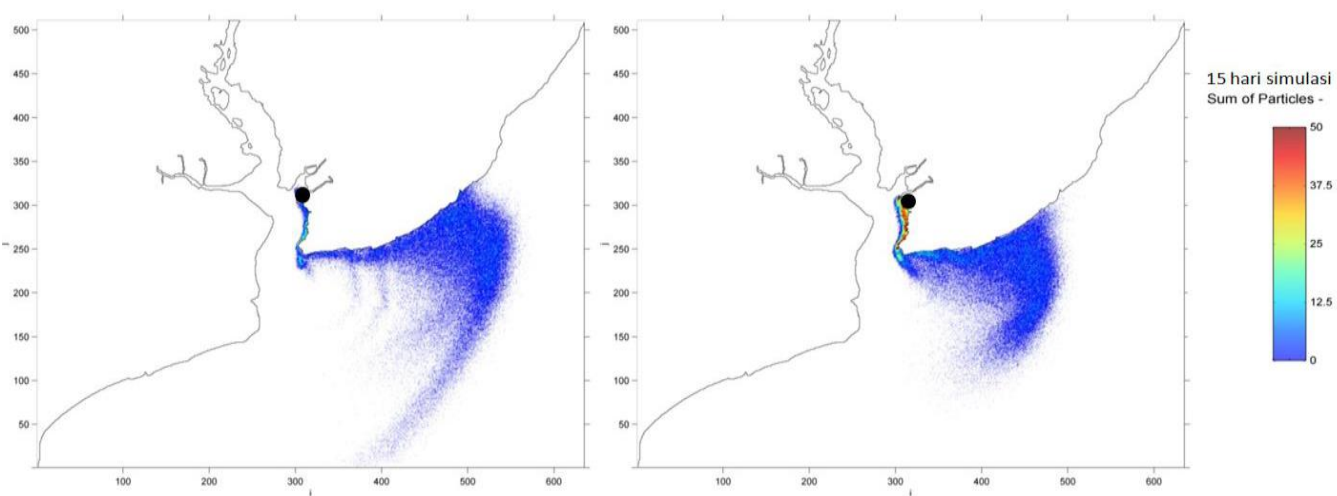

Gambar 10. Pola distribusi partikel selama 15 hari simulasi untuk Skenario 4 pada musim barat (kanan) dan musim timur (kiri)

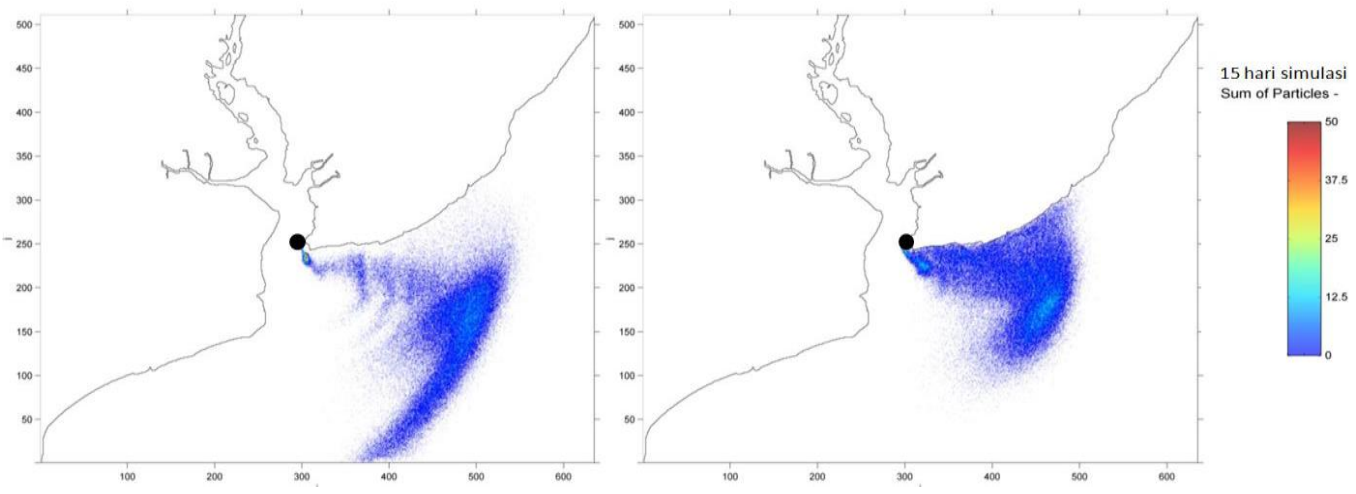

Gambar 11. Pola distribusi partikel selama 15 hari simulasi untuk Skenario 5 pada musim barat (kanan) dan musim timur (kiri)

\section{SIMPULAN}

Pada pemodelan dispersal ini yang ditinjau adalah sebaran partikel konservatif, dimana partikel dapat diasumsikan sebagai partikel sedimen yang tersuspensi. Dari hasil simulasi dapat disimpulkan bahwa terdapat perbedaan pola distribusi partikel sedimen tersuspensi antara musim barat dan musim timur, dimana sebaran partikel di musim barat bergerak lebih jauh dan lebih melebar daripada sebaran partikel di musim timur karena nilai kecepatan arus sungai ketika musim barat lebih besar $(0,71 \mathrm{~m} / \mathrm{s})$ daripada ketika musim timur $(0,2 \mathrm{~m} / \mathrm{s})$. Selain akibat pasang surut dan perbedaan arah angin, perbedaan pola tersebut juga dipengaruhi oleh perbedaan input kecepatan arus pada tiap musim di masing-masing sungai. Dari hasil simulasi juga terlihat bahwa sedimen yang terbawa dari hulu maupun hilir Sungai Riko memiliki konsentrasi yang tinggi di sekitar muaranya. Hal ini menandakan terjadinya sedimentasi di area tersebut. Karenanya diperlukan kajian lebih lanjut mengenai laju sedimentasi dengan memasukan data sedimen pada pemodelan transpor sedimen.

\section{UCAPAN TERIMA KASIH}

Ucapan terimakasih disampaikan kepada Research and Consultancy ASR Indonesia sebagai penyedia dana penelitian dan pemilik lisensi software pemodelan 3DDSuite. 


\section{DAFTAR PUSTAKA}

[1] Kelompok Kerja Erosi dan Sedimentasi., (2002). Kajian Erosi dan Sedimentasi Pada DAS Teluk Balikpapan Kalimantan Timur, Proyek Pesisir, TE-02/13-I, CRC/URI, Jakarta.

[2] Susyanto, M., (2018). "Studi Dinamika Sedimen Kohesif di Perairan Teluk Balikpapan dengan Menggunakan Model Numerik Tiga Dimensi”, Jurnal Geosains Kutai Basin, 1(1).

[3] Sinaga, A. T., Satriadi, A., Hariyadi, H., \& Novico, F. (2013). "Pola Sebaran Sedimen Tersuspensi Berdasarkan Model Pola Arus Pasang Surut Di Perairan Teluk Balikpapan, Kalimantan Timur", Journal of Oceanography, 2(3), 329-336.

[4] Black, K.P., (1996). The Hydrodynamic Model 3DD and Support Software. Occasional Report No.19. 53 pp.

[5] Black, K.P., (1996). Lagrangian Dispersal and Sediment Transport Model an Support Software. Occasional report no. 20. Department of Earth Sciences. University of Waikato and NIWA, Hamilton, New Zealand.

[6] Suciaty, F., Kemili, P., \& Harkey, T., (2018). "Analisis Sedimentasi di Sungai RikoPenajam Berdasarkan Pemodelan Hidrodinamika”, Prosiding Konteks 12, Batam.

[7] Padman, Laurie, and S. Erofeeva., (2005). "Tide Model Driver (TMD) Manual." Earth and Space Research.

[8] Dee, D. P., Uppala, S. M., Simmons, A. J., Berrisford, P., Poli, P., Kobayashi, S., Andrae, U., Balmaseda, M. A., Balsamo, G., Bauer, P., Bechtold, P., Beljaars, A. C. M., van de Berg, L., Bidlot, J., Bormann, N., Delsol, C., Dragani, R., Fuentes, M., Geer, A. J., Haimberger, L., Healy, S. B., Hersbach, H., Hólm, E. V., Isaksen, L., Kållberg, P., Köhler, M., Matricardi, M., McNally, A. P., Monge-Sanz, B. M., Morcrette, J.-J., Park, B.-K., Peubey, C., de Rosnay, P., Tavolato, C., Thépaut, J.-N. and Vitart, F. ,(2011). "The ERAInterim reanalysis: configuration and performance of the data assimilation system", Q.J.R. Meteorol. Soc., 137: 553-597. doi: 10.1002/qj.828 
Fitri Suciaty, Putri Kemili, Tommy Harkey

Jurnal Itenas Rekayasa - 204 